\title{
REVIEW \\ Characteristics and Seedling Establishment of Rice Nursling Seedlings
}

\author{
Ryouji SASAKI ${ }^{*}$ \\ Graduate School of Agricultural Science, Tohoku University (Sendai, Miyagi 981-8555, Japan)
}

\begin{abstract}
A "rice nursling seedling" is the youngest stage of rice seedling transplanted by machine in Japan, and is defined as a seedling of 2 to 3 plant age in leaf number. However, changes in morphological and physiological characteristics of the seedling during this stage of development are not fully understood. This study was undertaken to obtain the ideal plant age of rice nursling seedlings which would give excellent seedling establishment. When plant age of rice seedlings was approximately 2.4 , substantial photosynthesis occurred and plant length was over $7 \mathrm{~cm}$, which is required for mechanical transplanting. The transplanted nursling seedlings with this age developed depending on the emerging crown roots from the first node, and it was suggested that crown roots from the coleoptilar node played a role in the absorption of water and nutrients just after transplanting. When rice nursling seedlings exceeded the age of 2.6, characters of the seedling degraded, and this was aggravated by high-density seeding. Rice seedlings with plant age of 2.5 showed the highest level of submergence tolerance among rice seedlings with several plant ages. The results suggest that plant ages of $2.3-2.5$ are the ideal ages for transplantation of rice nursling seedlings.
\end{abstract}

Discipline: Crop production

Additional key words: plant age in leaf number, transplanting, rooting, submergence

\section{Introduction}

Mechanical transplanting was introduced to rice cultivation of Japan in the early 1960s. Transplanting culture is carried out in over $99 \%$ of the planted rice area in Japan. A "rice nursling seedling" is the youngest stage of seedling transplanted by machine. The growth period for nursling seedlings is usually from 5 to 14 days. It is the shortest among seedlings, so labor and materials inputs can be reduced. Since nursling seedlings are smaller compared to other older seedlings, dense seeding and a reduction in the number of nursery boxes can also be achieved. The culture of rice nursling seedlings for transplanting has created considerable interest in recent years as a way to reduce working time and cost. On the other hand, nursling seedlings had the demerit that their root spread into the bed soil in a nursery box was too weak to be used for mechanical transplanting because of the absence of interlocking roots, which resulted from the underdeveloped crown roots. However, this weakness has been solved due to the invention of a nursery mat made from rockwool.

A rice nursling seedling is defined as a seedling of 2 to 3 plant age in leaf number, including the incomplete leaf. However, there are obvious changes in morphological and physiological characteristics of the seedling during this stage of development. Therefore the main objective of our research was to obtain the ideal plant age of nursling seedlings, which would give excellent seedling establishment after transplanting. It is necessary and important to understand the following; (i) the developmental changes of the energy dependence and the morphological characteristics of the nursling seedlings, (ii) the effects of growth period and seeding density on the character of the nursling seedlings, (iii) the role of crown roots from the coleoptilar node and the first node in the establishment and development of transplanted nursling seedlings, and (iv) changes in the capacity to establish under unfavorable conditions after transplanting, e.g.

\footnotetext{
Present address:

${ }^{1}$ National Agricultural Research Center (Joetsu, Niigata 943-0193, Japan)

*Corresponding author: fax +81-25-524-8578; e-mail ryouji@affrc.go.jp

Received 2 October 2003; accepted 30 October 2003.
} 
submergence, low temperature, and wind etc. This report presents an outline of our recent studies.

\section{Changes in energy dependence and morphological characteristics with the development of rice nursling seedlings ${ }^{10}$}

The developmental changes in energy dependence, from a reliance on endosperm reserves to reliance on photosynthetic tissue, and the morphological characteristics of rice nursling seedlings were examined. The seedlings were raised in temperature-controlled greenhouses with a day/night cycle set at $30 / 25^{\circ} \mathrm{C}, 24 / 19^{\circ} \mathrm{C}$, and $17 /$ $12^{\circ} \mathrm{C}$ after emergence. The variety of rice used for all experiments was Sasanishiki, which was a major variety in the northern part of Japan. Plant length of more than 6 $\mathrm{cm}^{17}$ or $7 \mathrm{~cm}^{1,7}$ was required for transplanting of nursling seedlings using a conventional transplanting machine. Seedlings with plant age of 2.4 attained the required plant length under the 3 temperature conditions (Fig. 1A). It was conjectured that crown roots from the coleoptilar node had already emerged near plant age of 2.4 (Fig. 1B), since the number of crown roots is generally 5 per plant.

The growth of the seedlings was compared to that of seedlings raised in the dark in the same greenhouse. The relationship between the consumption of endosperm nutrients and the dry weight of shoots was represented by 2 regression lines for the seedlings raised in light, but was represented by one regression line for those raised in the

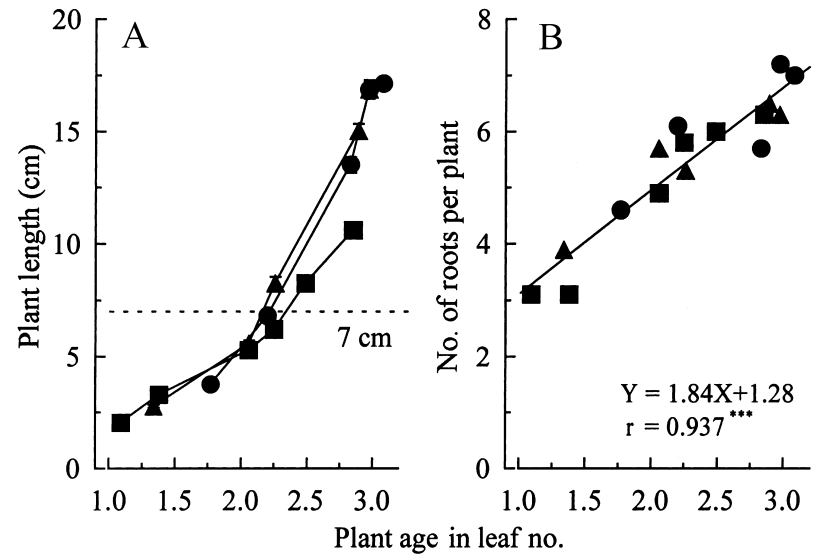

Fig. 1 The relationships between plant age in leaf number and plant length (A), and number of roots (B) under natural light conditions

Temperature conditions were $30 / 25^{\circ} \mathrm{C}$ ( ), 24/ $19^{\circ} \mathrm{C}(\boldsymbol{\Delta})$ and $17 / 12^{\circ} \mathrm{C}(\boldsymbol{\square})$ with a day/night cycle of $12 / 12 \mathrm{~h}$. The horizontal dotted line indicates a plant length of $7 \mathrm{~cm}$. The vertical bars represent the standard error of 15 plants, if those are longer than the symbols. $* * *$ : Significant at $0.1 \%$ level. dark (Fig. 2). The light regression slopes were significantly different from that of the dark after $74 \%$ of the endosperm reserves were consumed and plant age reached 2.4 (Fig. 3). As the consumption of endosperm nutrients increased, the ratio of the shoot dry weight to the consumption of endosperm nutrients in light increased about threefold, (i.e., from 0.48 to 1.43 ). This change was due to an increase in the energy received from photosynthesis. In rice seedlings it has been reported that the photosynthesis of rice seedlings grown

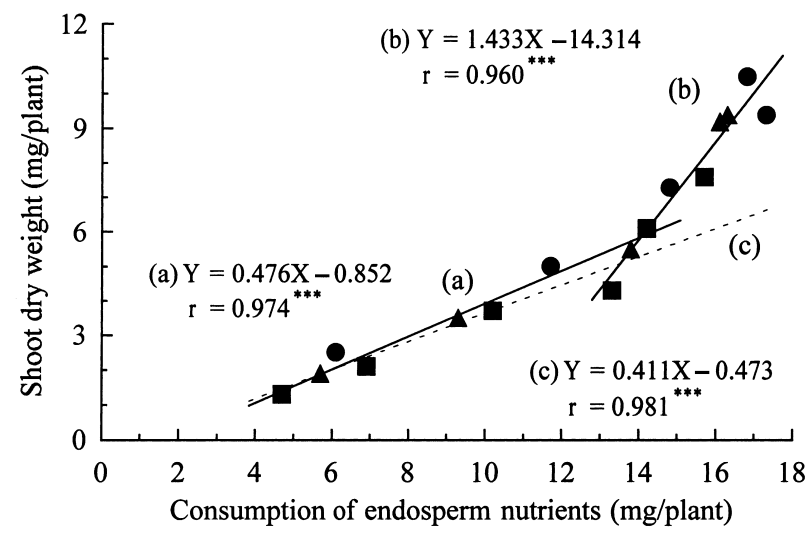

Fig. 2. The relationship between the consumption of endosperm nutrients and shoot dry weight under natural light conditions

Temperature conditions were $30 / 25^{\circ} \mathrm{C}$ ( ), 24/ $19^{\circ} \mathrm{C}(\boldsymbol{\Delta})$ and $17 / 12^{\circ} \mathrm{C}(\boldsymbol{\square})$ with a day/night cycle of $12 / 12 \mathrm{~h}$. The dotted line (c) indicates a regression line obtained under dark conditions but data for dark conditions were omitted. ***: Significant at $0.1 \%$ level.

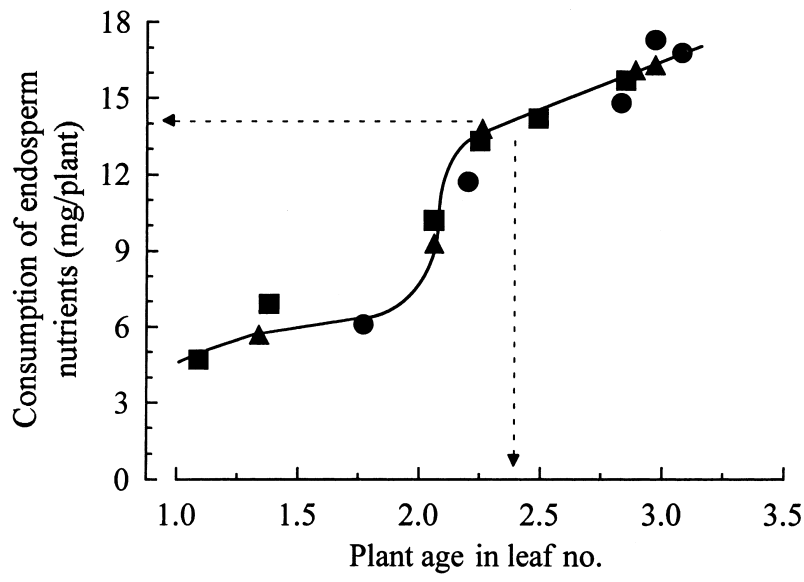

Fig. 3. The relationship between plant age in leaf number and consumption of endosperm nutrients under natural light conditions

Temperature conditions were $30 / 25^{\circ} \mathrm{C}$ ( ) , 24/ $19^{\circ} \mathrm{C}(\boldsymbol{\Delta})$ and $17 / 12^{\circ} \mathrm{C}(\boldsymbol{\square})$ with a day/night cycle of $12 / 12 \mathrm{~h}$. 
in light occurs before an age of $2 \cdot 0^{2,3}$. However, our results suggested that the quantity of complex organic compounds derived from the photosynthetic tissue of seedlings prior to a plant age of 2.4 was negligible compared to those derived from the endosperms. It was conjectured that substantial photosynthesis occurred at plant age of 2.4-2.5.

\section{The role of crown roots from the coleoptilar node and the first node in the rooting and development of transplanted rice nursling seedlings ${ }^{11}$}

The rooting and establishment of transplanted rice seedlings, including nursling seedlings, depends on the growth of new roots ${ }^{2,4,5}$. This is associated with the character of the seedling ${ }^{4,9}$ and amount of damage incurred $^{4,9,18}$. Root pruning, which accompanies transplanting, is the principle cause of this damage. The root system of rice nursling seedlings is composed of a seminal root and crown roots from the coleoptilar node. It was reported that the coleoptilar node's crown roots were the key roots involved in rooting and development of transplanted nursling seedlings ${ }^{6}$. Knowledge of the influence of cut crown roots from the coleoptilar node on rooting is needed to evaluate the role of the crown roots in the rooting and establishment of nursling seedlings.

The roots were cut at various locations, and the treated seedlings were grown for 7 days after transplanting. It was reported that other advanced seedlings having roots $3 \mathrm{~cm}$ long or more from their base showed little differences in taking root or early growth after transplanting ${ }^{18}$. In a nursling seedling, even when all roots were cut at $1.5 \mathrm{~cm}$ from the base of the root, growth of the seedling was similar to that of seedlings without the treatment ${ }^{11}$. However, the growth was significantly reduced when cut at a length of $0.5 \mathrm{~cm}$ from the base ${ }^{11}$. It was not clear whether the influence of the $0.5-\mathrm{cm}$ treatment on the growth resulted from total length of roots cut by the treatment, or from restricting the elongation of coleoptilar nodal roots by the treatment.

In the following experiment, therefore, two kinds of root cutting treatments were performed to this region; cutting off the root tip, and cutting the base of the root. The root tip region includes the root apex, the root cap and the cell division zone of the root $^{5,8}$. The growth of transplanted seedlings, including the emergence rate of the third leaf, was barely influenced by excision of the root tips of a seminal root and 4 crown roots, but the growth was severely reduced by cutting at the bases of a seminal root and the longest crown root (Fig. 4). These results indicate that the rooting and development of transplanted nursling seedlings are reduced according to the

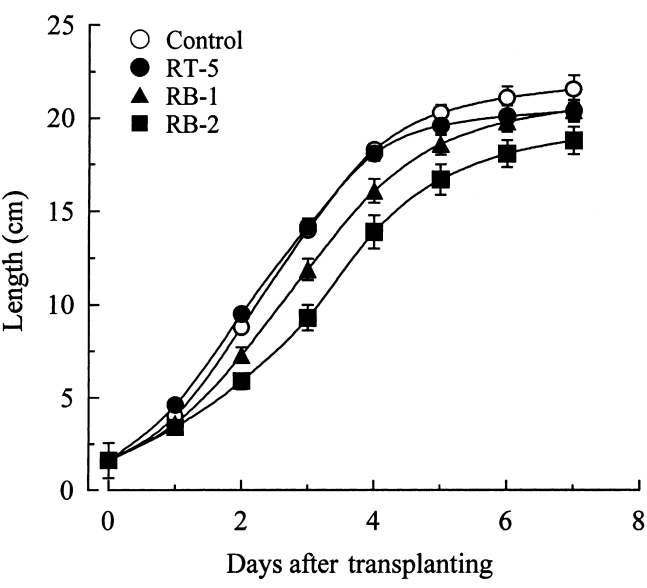

Fig. 4. Effects of root cutting treatments just before transplanting on the length of the third leaf as it emerged from the second leaf sheath

RT-5: A seminal root and 4 crown roots were cut off $2 \mathrm{~mm}$ from root tip. RB-1: A seminal root was cut off at its base. RB-2: A seminal root and the longest crown roots were cut off at their base. After transplanting, the treated and non-treated (control) plants were grown in a temperature-controlled greenhouse set at $30 / 25^{\circ} \mathrm{C}$ with a day/night cycle of $12 / 12 \mathrm{~h}$. Vertical bars represent the standard error of 6 plants.

total length of the root remaining after treatment ${ }^{11}$. It was conjectured that the crown roots from the coleoptilar node played a large role in the absorption of water and nutrients just after transplanting, and promoted the rooting and development of transplanted nursling seedlings through emergence of the first nodal roots.

\section{Characteristics of rooting and early growth of transplanted rice nursling seedlings with various plant ages in leaf number ${ }^{12}$}

The rooting and development of transplanted rice seedlings are affected by the character of the seedling as well as the amount of damage to roots. An experiment was conducted to examine the influences of these factors on the rooting and early growth of transplanted rice nursling seedlings. The number of roots at 8 days after transplanting was higher in nursling seedlings with older plant ages compared with younger plants ${ }^{12}$. However, transplanting injury, indicated by the rate of leaf emergence at $0-4$ days after transplanting, was observed when the plant age of a transplanted seedling exceeded 2.6 in leaf number (Fig. 5). This was primarily due to an imbalance between the total length of the leaf blade and that of the roots. Furthermore, high-density seeding aggravated this transplanting injury (Fig. 5), and a difference in rela- 


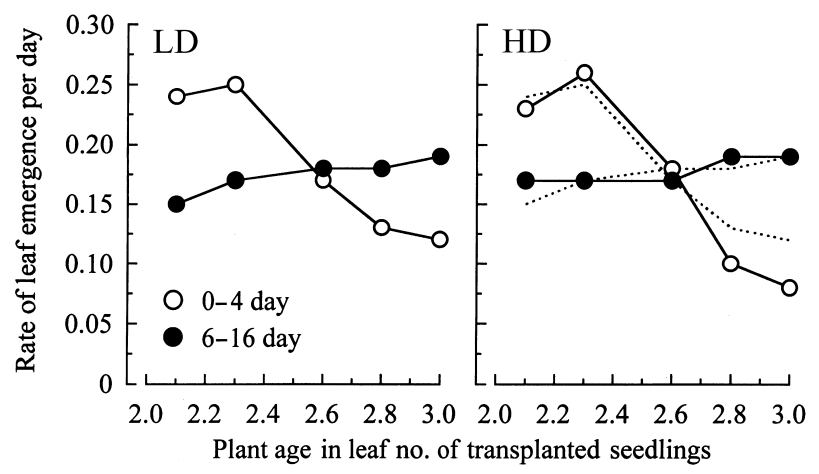

Fig. 5. Changes in the rate of leaf emergence during 4 days after transplanting and during 10 days from 6 to 16 days after transplanting

The rate of leaf emergence was the slope of the regression lines calculated by daily measurement data. Seeding density was $200 \mathrm{~g}$ per nursery box (LD: standard density of nursling seedlings) and $300 \mathrm{~g}$ per nursery box (HD). Dotted lines indicate values of $L D$.

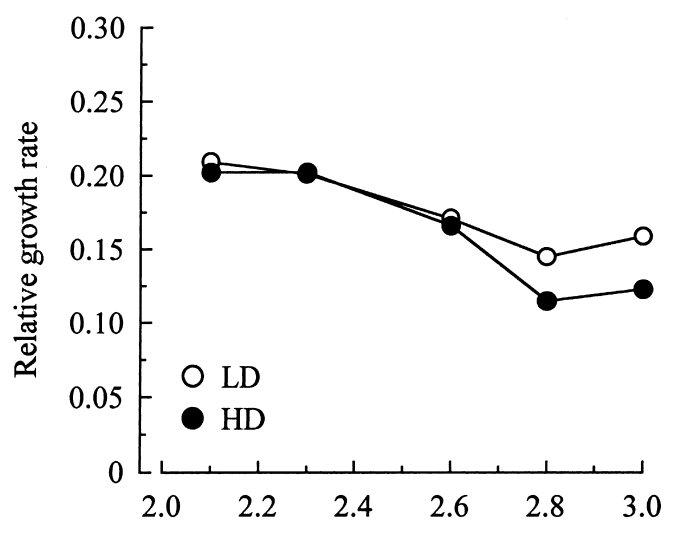

Plant age in leaf no. of transplanted seedlings

Fig. 6. Relative growth rate during 8 days after transplanting Seeding density was $200 \mathrm{~g}$ per nursery box (LD) and $300 \mathrm{~g}$ per nursery box (HD).

tive growth rate for 8 days after transplanting between both seeding densities was observed for seedlings with 2.8- and 3.0-plant age (Fig. 6). These results suggest that the characters of seedlings greatly degrade when a plant exceeds an age of 2.6 in leaf number.

Submergence tolerance of transplanted rice seedlings with several plant ages in leaf number

Low temperature and wind are the most important environmental factors affecting establishment of transplanted rice seedlings in the northern part of Japan. In our experiments ${ }^{13}$, leaf elongation growth was severely inhibited when rice nursling seedlings were exposed to

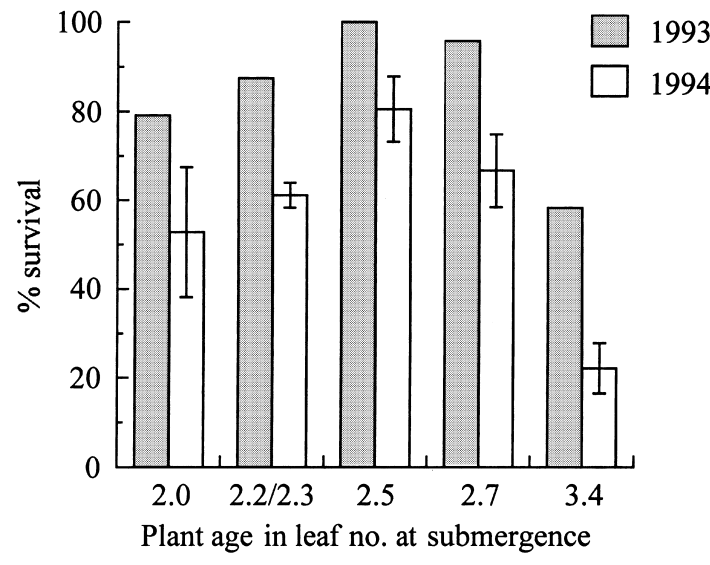

Fig. 7. Survival of rice seedlings with several plant ages in leaf number at submergence

All seedlings were completely submerged for 10 days. Plant survival was measured at 20 days (1993) and 25 days (1994) after transplanting, i.e. 10 days and 15 days after de-submergence, respectively. Vertical bars in 1994 represented the standard error of 3 replications and there was no replication in 1993.

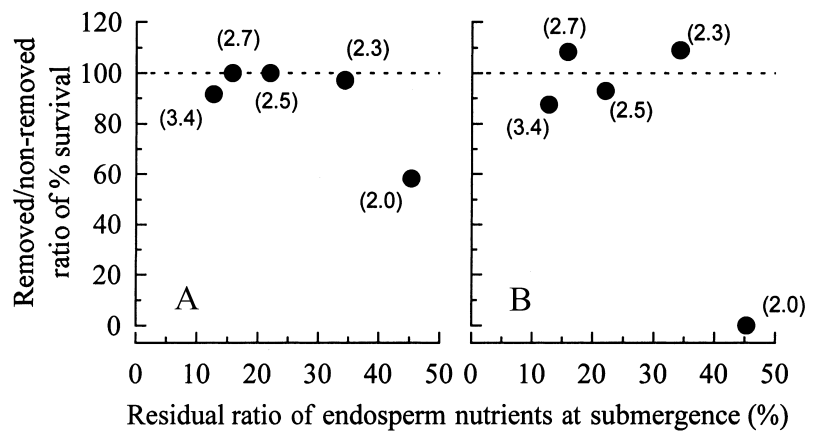

Fig. 8. Role of endosperm reserves in percent survival of rice seedlings with several plant ages (1994)

Endosperm was removed just before transplanting. The treated and non-treated seedlings were submerged for 5 days (A) and 10 days (B) after transplanting. Values in parentheses are plant age in leaf number of transplanted seedlings.

wind and low temperature after transplanting; a root cutting treatment at transplanting aggravated the inhibition of leaf elongation growth. Deeper flooding during a few days after transplanting can alleviate this influence, but rice seedlings may become either partly or completely submerged because of shorter plant length of nursling seedlings and unevenness in a paddy field. Work presented here focuses on the difference in survival of transplanted and completely submerged rice seedlings with several plant ages in leaf number ${ }^{14,15}$.

\section{The duration of submergence and the role of endosperm reserves ${ }^{14}$}

Rice seedlings with plant ages of 2.0, 2.2/2.3, 2.5, 
2.7, and 3.4 in leaf number (5 to 21-day-old seedlings) were used in 1993 and 1994. When the seedlings were completely submerged for 5 days after transplanting, all survived. When they were submerged for 10 days, however, the elongation of plant length was promoted and conversely growth of the roots was suppressed ${ }^{14}$. The percent survival of the nursling seedlings ranged from $79 \%$ to $100 \%$ in 1993 , and ranged from $53 \%$ to $81 \%$ in 1994; which were higher than those of seedlings with a plant age of 3.4 (Fig. 7). In particular, the percent survival of seedlings with a plant age of 2.5 was highest among the seedlings. When endosperm reserves were removed from the seedlings just before transplanting, a reduction in elongation growth and percent survival was hardly observed in the seedlings, except for those with a plant age of 2.0 (Fig. 8). The results indicate that the dif-

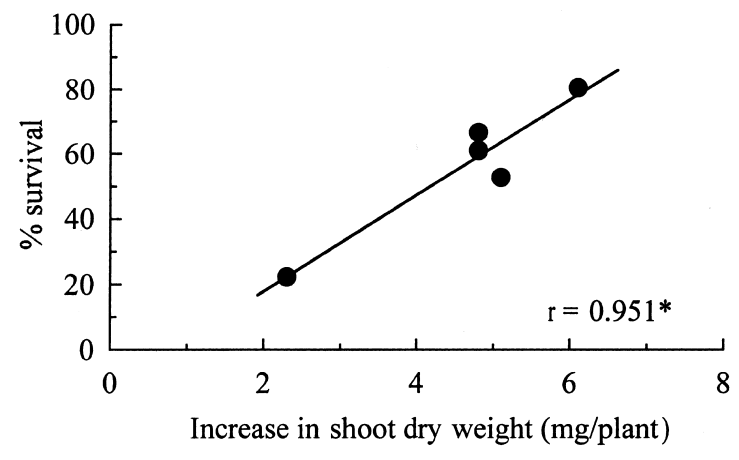

Fig. 9. Relationship between increase in shoot dry weight during submergence for 8 days and percent survival (1994)

Plant survival was measured at 25 days after transplanting. *: Significant at $5 \%$ level.

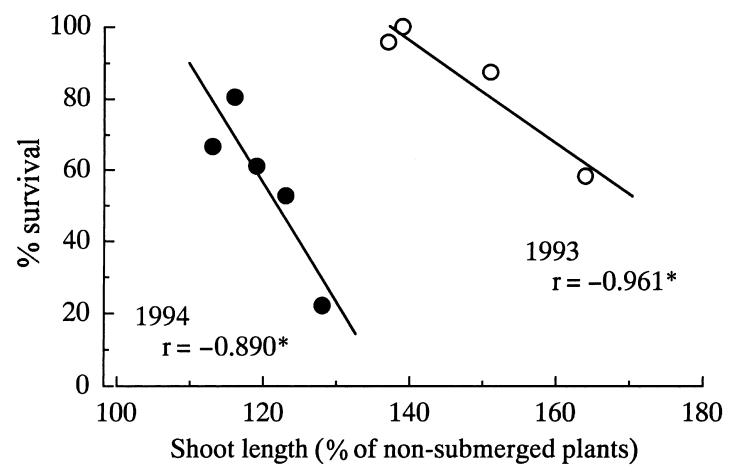

Fig. 10. Relationship between shoot elongation of rice seedlings during submergence for 10 days and survival

Shoot length is expressed as a \% of plant length of non-submerged plants. *: Significant at $5 \%$ level. ference in percent survival among the seedlings cannot be explained by the amount of the residual endosperm reserves at the start of submergence.

\section{Relationship between growth during submergence and survival ${ }^{15}$}

The percent survival of seedlings positively correlated with the increase in shoot dry weight during submergence (Fig. 9). In contrast, a negative correlation between elongation growth (\% of non-submerged seedlings) and percent survival was observed in each year (Fig. 10). This result agrees with that obtained at IRRI ${ }^{16}$,

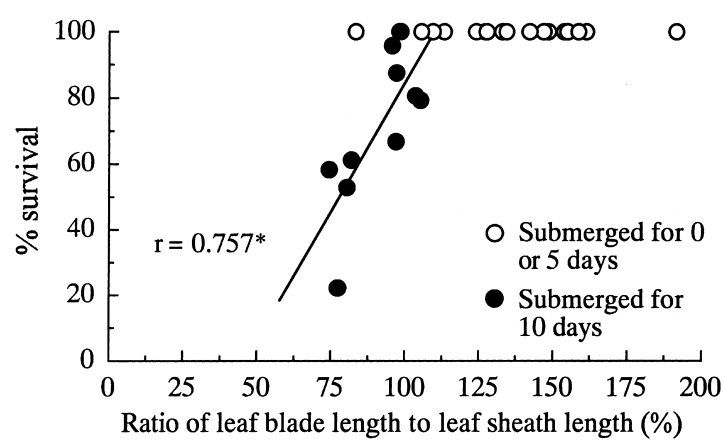

Fig. 11. Relationship between the ratio of leaf blade length to leaf sheath length and percent survival

Ratio of leaf blade length to leaf sheath length was calculated by the third leaf in seedlings with plant ages of 2.0-2.7 and was calculated by the fourth leaf in seedlings with plant age of 3.4. Results obtained in 1993 and 1994 are shown without distinguishing the year. *: Significant at 5\% level.

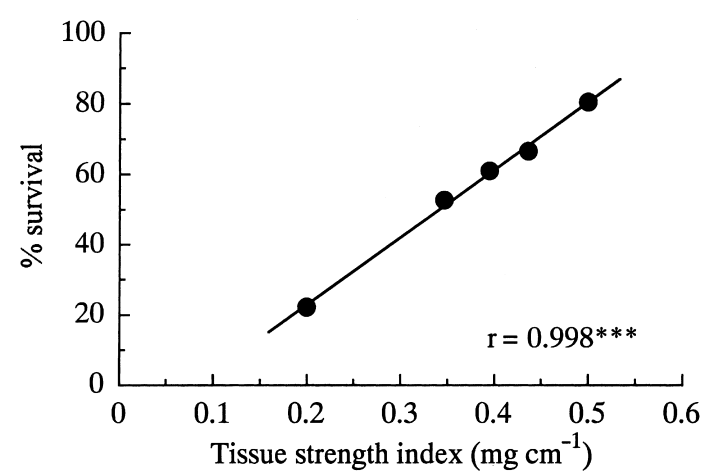

Fig. 12. Relationship between the tissue strength index and percent survival (1994)

The tissue strength index was defined as the ratio of the increase in shoot dry weight during submergence for 8 days to the length of leaf sheath of the third leaf or the fourth leaf at the end of submergence. The third leaf of rice seedlings with plant ages of 2.0-2.7 and the fourth leaf of rice seedlings with plant age of 3.4 at submergence were measured at the end of submergence, i.e. at 10 days after transplanting. $* * *$ : Significant at $0.1 \%$ level. 


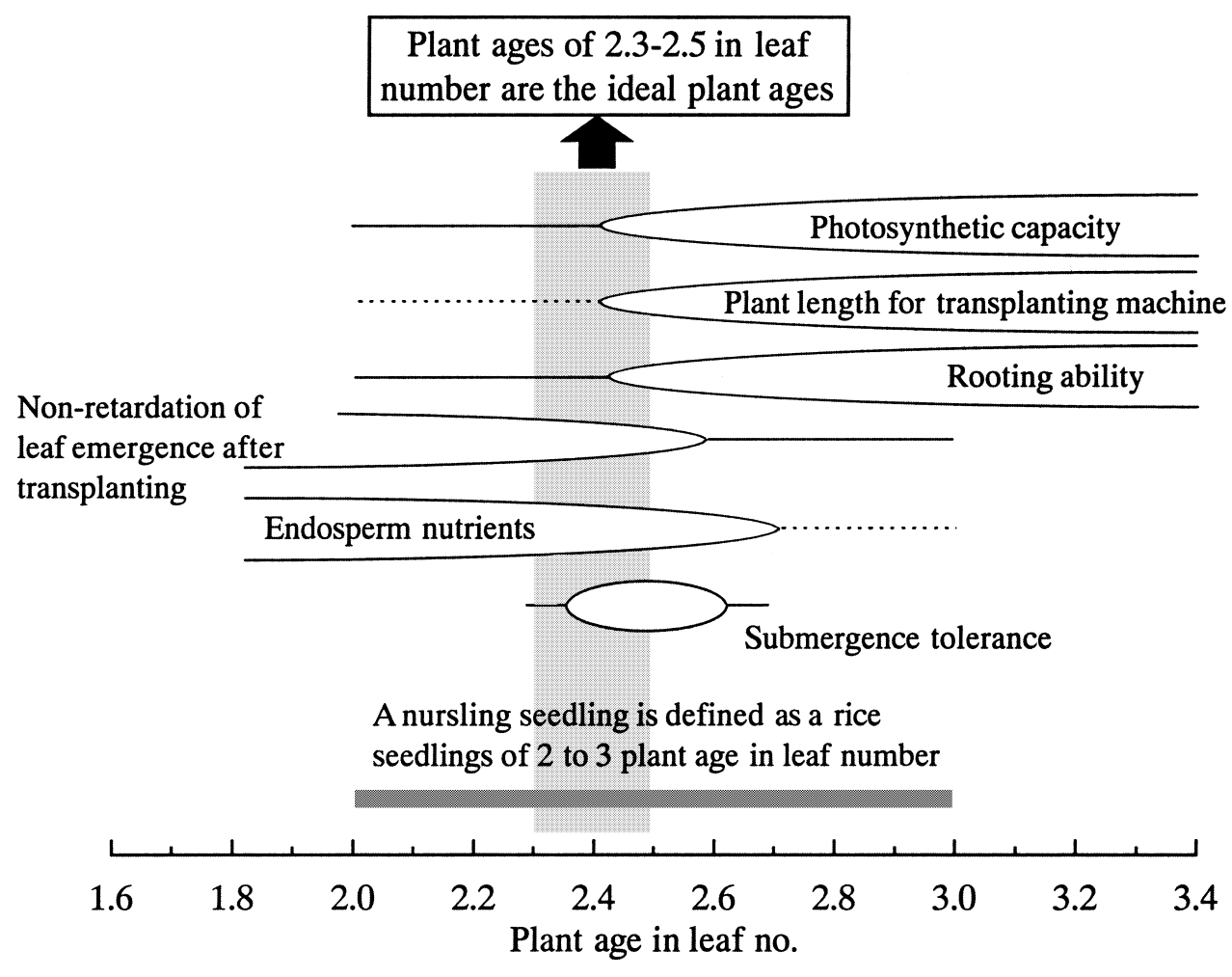

Fig. 13. Diagrammatic representations of the developmental changes in rice nursling seedlings and the ideal plant ages of nursling seedlings for transplantation

and suggests that low elongation growth during submergence is essential for survival. When the length of the leaf sheath was longer than that of the leaf blade under submergence, the percent survival decreased; the percent survival in both 1993 and 1994 was reflected by a regression line (Fig. 11). The tissue strength index was defined as the ratio of increase in shoot dry weight during submergence for 8 days to the length of leaf sheath at the end of submergence, provided that elongating leaves (cf. Fig. 12) at the start of submergence were measured. A strong positive correlation was found between the tissue strength index and the percent survival (Fig. 12). These results suggest that the difference in submergence tolerance among the seedlings is due to the difference in elongation growth, which is dependent on the leaf developmental stage and carbohydrates supplied to the growing zone of elongating leaves.

\section{Ideal age of rice nursling seedlings for transplantation}

From the above consideration we suggest that plant ages of 2.3-2.5 in leaf number are the ideal ages of rice nursling seedlings for transplantation (Fig. 13). Owing to the ideal age of rice nursling seedlings proposed in our work, nursling seedlings can be utilized to their potential capacity for transplanting. The results of our research will be useful in establishment of an appropriate technique to culture them.

\section{References}

1. Himeda, M. (1994) Cultivation technique of rice nursling seedlings. Review of research papers and its future implementation. Agric. Hortic., 69, 679-683, 791-796 [In Japanese].

2. Hoshikawa, K. (1971) Physiology of "young" rice seedling and its raising technique. Nobunkyo, Tokyo, 30-192 [In Japanese].

3. Hoshikawa, K. \& Ishii, R. (1974) Gas exchange characteristics of "young" rice seedlings raised in box. Proc. Crop Sci. Soc. Jpn, 43 (Extra issue 1), 5-6 [In Japanese].

4. Hoshikawa, K. (1976) Theory and technique on the raising of paddy rice seedlings for mechanical transplanting (35). Agric. Hortic., 51, 354-358 [In Japanese].

5. Hoshikawa, K. (1989) The growing rice plant. An anatomical monograph. Nobunkyo, Tokyo, 11-205.

6. Hoshikawa, K. \& Shoji, K. (1990) Nursling seedlings, their optimum ages for good rooting and the mechanism of rooting. Jpn. J. Crop Sci., 59 (Extra issue 2), 173-174 [In Japanese].

7. Kiriyama, T. (1991) Uniformity in the number of transplanting endosperm rice seedling. Hokuriku Crop Sci., 26, 20-21 [In Japanese].

8. Matsuo, T. \& Hoshikawa, K. (1993) Science of the rice plant. Morphology. Food and agriculture policy research 
center, Tokyo, 123-132.

9. Mimoto, H. (1983) Studies on the seedling establishment of transplanted lowland rice in the northern part of Tohoku district. Bull. Aomori Agric. Exp. Stn., 27, 1-69 [In Japanese with English summary]

10. Sasaki, R. \& Hoshikawa, K. (1997) Changes in energy dependence and morphological characteristics with the development of rice nursling seedlings raised under different light and temperature conditions. Jpn. J. Crop Sci., 66, 252-258.

11. Sasaki, R. \& Hoshikawa, K. (1997) The role of crown roots from coleoptilar node in the rooting and development of transplanted rice nursling seedlings. Jpn. J. Crop Sci., 66, 259-267.

12. Sasaki, R. \& Gotoh, K. (1999) Characteristics of rooting and early growth of transplanted rice nursling seedlings with several plant ages in leaf number. Jpn. J. Crop Sci., 68, 194-198 [In Japanese with English summary].

13. Sasaki, R. (2000) Rooting of the nursling seedlings of rice exposed to low temperature and wind after transplanting. Jpn. J. Crop Sci., 69, 140-145 [In Japanese with English summary].

14. Sasaki, R. \& Zhao, Z. C. (2000) Submergence tolerance of transplanted rice seedlings with several plant ages in leaf number - The duration of submergence and the role of endosperm reserves —. Jpn. J. Crop Sci., 69, 365-371 [In Japanese with English summary].

15. Sasaki, R. \& Zhao, Z. C. (2000) Submergence tolerance of transplanted rice seedlings with several plant ages in leaf number - Relationship between the growth during submergence and survival- Jpn. J. Crop Sci., 69, 372379 [In Japanese with English summary]

16. Setter, T. L. \& Laureles, E. V. (1996) The beneficial effect of reduced elongation growth on submergence tolerance of rice. J. Exp. Bot., 47, 1551-1559.

17. Tsuga, K. et al. (1994) Study on the adaptability of transplanter for rice infant seedlings. Tech. Rep. Inst. Agric. Dec., 28, 67-79 [In Japanese with English summary].

18. Yamamoto, Y. (1991) Studies on transplanting injury and its culture significance in rice plant. Mem. Fac. Agric. Kochi Univ., 54, 1-167 [In Japanese with English summary]. 